\title{
Time, precarisation and age normality: on internal job mobility among men in manual work
}

\author{
Clary Krekula \\ Department of Social and Psychological Studies, Karlstad University, Karlstad, Sweden \\ Email: clary.krekula@kau.se
}

(Accepted 19 September 2018; first published online 31 October 2018)

\begin{abstract}
This article explores the conditions for extended working life from an organising perspective. Based on the idea that temporality makes up a fundamental organising dimension, it discusses conceptions of internal job mobility, and if and when employees are expected to relocate to a different unit at work. The material consists of interviews with 11 men between the ages of 56 and 74, working in manual and managerial capacities at a foundry of a Swedish branch of a large international steel company. The results show that internal work mobility is regulated by normative assumptions of mobility in terms of on- and offtime. This socio-temporal order constructs younger age groups as the age normality while designating the older employees' transitions as a normative breach. It is also shown that the temporal order constitutes a disciplining element steering employees from an early stage to plan for limitations that may arise as a result of ageism and/or physical changes. The result confirms that transition to less-physically demanding tasks is a prerequisite for continuing working in a physically demanding job. These transitions are not, however, included in the socio-temporal order of the company, but are presented as the older employees' individual problem. All together, these results show the need to introduce organisational practices and corporate strategies in the debate on extended working life.
\end{abstract}

Keywords: age normality; extended working life; internal job mobility; marked-unmarked age; precarisation; temporal organising; temporal regimes

\section{Introduction}

Since the end of the 1990s, there has been a rapid increase of policies supporting extended working life (Phillipson, 2019). The policies have tended to focus on individuals, and the debate has to a great extent described older people as the problem. Their participation in working life and current retirement trends are described as problematic as well as self-serving, uninformed and out-dated, and as a threat to welfare provision and benefits (Krekula and Vickerstaff, 2017). Many governments have therefore focused on trying to persuade older workers to make 'wiser' decisions and delay their retirement, for example, by creating favourable conditions

(C) Cambridge University Press 2018. This is an Open Access article, distributed under the terms of the Creative Commons Attribution licence (http://creativecommons.org/licenses/by/4.0/), which permits unrestricted re-use, distribution, and reproduction in any medium, provided the original work is properly cited. 
for older people who are able and willing to continue working (Krekula et al., 2017b), by making work pay through tax incentives (Vickerstaff and Loretto, 2017) and by narrowing gateways to early exit (Smeaton and White, 2016).

The description of extended working life as a simple matter of older workers' individual choice is contradicted by research, which shows that work content factors influence labour market participation in later life (Pohrt and Hasselhorn, 2015; Smeaton and White, 2016). The description is also debatable in view of research on work ability, i.e. the balance between the demands of work and the resources of the individual, which, together with motivation and the opportunity to work, is described as intermediate steps to early retirement (Takala and Seitsamo, 2015). Research has also shown that ageism, e.g. in the form of discrimination, negative attitudes and a stereotypical picture of older workers (for the concept, see Butler, 1969; Wilkinson and Ferraro, 2002), forces people out of working life (Ilmarinen, 1997, 2006; Bennington, 2001). Regardless of whether the categorisation 'older workers' is applied to middle-aged people, to elderly people or to people over the age of 50, older workers are discursively described as having a subordinated position in work organisations (Riach, 2009; Fevre, 2011; Krekula and Vickerstaff, 2017).

Age-based marginalisation affects individuals' wellbeing and their will to work. Research shows, for example, that perceived ageism affects subjective health (Cadiz, 2010; World Health Organization, 2015), and that older workers are more prone to staying in workplaces that are less ageist (Cadiz, 2010). Behind the rhetoric about self-serving, uninformed and problematic older workers, there are thus welldocumented organisational practices which create age-based marginalisation and limit older people's participation in working life. The necessary conditions for extended working life need to be explored in a broader political and social context, and the debate needs to be based on knowledge of how age-based marginalisation and the organisational practices of the workplace relate to retirement decisions (Hasselhorn and Apt, 2015; Krekula and Vickerstaff, 2017; Phillipson, 2019).

This article is a contribution to this debate by highlighting conceptions of the age at which employees are expected to change work station and duties in workplaces with physically demanding jobs. On the basis of qualitative interviews with men aged 56-74 in an industrial company and on the assumption that temporality makes up a fundamental dimension of an organisation, I identify the presence of temporal norms related to internal work mobility. By showing that the temporal order (Zerubavel, 1981) affects older workers' possibilities to stay at work, the article problematises the notion that working life in physically demanding workplaces can be extended through shifting work tasks. The article also illustrates that the temporal norms related to internal work mobility at an early stage influence individuals to plan for limitations that they fear will arise as a result of ageism in the future.

\section{Literature survey}

In a context of considerable economic decline in the industrial sector in Organisation for Economic Co-operation and Development (OECD) countries from the end of the 1970s to the early 1990s, policies at the time aimed to facilitate early retirement, and research focused on the characteristics of early exit. Against the backdrop of population ageing, more recently the focus has shifted, both in 
policies and in research, to analyse the possibility of people extending their working lives into their sixties and seventies (Van Dalen and Henkens, 2002; Phillipson, 2019). When extended working life is currently implemented in many countries, it takes place in a context with a gap between what older adults want and need and what they are offered by policy makers and employers (James et al., 2016), where opportunities for full-time employment are restricted (Phillipson, 2019), labour force participation rates for prime working-age men, i.e. 25-54, have been falling (Dvorkin and Shell, 2015) and employments with uncertain pension terms and guaranteed hours are on the increase (OECD, 2015).

At the same time, retirement is transforming from being a shift from full-time work to full and permanent retirement into a process of stages over several years (Sonnega et al., 2016). Cahill et al. (2015: 385) refer to the process as the 'do-it-yourself approach to retirement, including phased retirement from full-time to part-time work to full retirement, and transitions from a full-time career job to another, shorter duration job to full retirement, e.g. intermediate jobs or 'bridge jobs'. Research also indicates the existence of 'unretirement', in which workers return either to full- or part-time work after full retirement (Maestas, 2010). According to Kail and Warner (2013), to a great extent unretirement means that men resume full-time work and women return to part-time work.

Research indicates a number of factors that affect older workers' participation in working life, namely health, economic incentives, physical and psycho-social work environment, family/leisure, rate of work and working hours, the competence and skills of senior staff, work satisfaction, and attitudes to older employees (Nilsson, 2016). At a general level, the reason for people retiring has been described as an interaction between (a) 'push' factors, e.g. no appreciation of or demand for older workers; (b) 'pull' factors, e.g. voluntary retirement for assumed economic reasons; and (c) 'jump' factors, e.g. retirement as a way of ageing with pleasure (Lund and Villadsen, 2005; Thorsen et al., 2012).

Research indicating that marginalisation and exclusion of the elderly are obstacles to older people's participation in the labour market (Ilmarinen, 1997, 2006; Bennington, 2001; European Commission, 2009) is also central to the present study. In the same vein, there is research showing that opportunities for development are associated with remaining at work or late retirement (Thorsen et al., 2012).

Marginalisation of older workers also emerges in studies showing that long-term unemployment increases with age (Henkens et al., 1996; Schwartz and Kleiner, 1999); that older workers have the lowest re-employment probabilities (Yearta and Warr, 1995; Loretto et al., 2000; Chan and Stevens, 2001; Kalavar, 2001; Gee et al., 2007); that older people are not called in for job interviews (Benedick et al., 1999; Nelson, 2005; Neumark, 2009); and that they have high probabilities of part-time employment while suffering the largest wage losses (Hirsch et al., 2000; Bennington, 2001). However, the quality of life at work seems to affect men and women's retirement planning differently (Larsen, 2008). Ageism, lack of recognition and lack of development opportunities are associated with older male workers' retirement plans (Thorsen et al., 2012). Perceived ageism is described as a significant factor for retirement before the average retirement age among men, but not among women (Soidre, 2005). 
Concurrent with the ongoing debate on extended working life, research shows that older employees experience a growing discontent with work demands and the nature of work (Smeaton and White, 2016). This is in harmony with studies of work factors in relation to the employment participation of older workers, where heavy physical work demands have consistently been associated with disability retirement (Lund and Villadsen, 2005; Pohrt and Hasselhorn, 2015). It is also argued that work ability declines with age, especially in jobs with physically demanding tasks, and that some older workers are stuck in jobs that are physically demanding, which has been explained by their low levels of education (Takala and Seitsamo, 2015). Further, the quality of an individual's working life may affect women and men differently. Blekesaune and Solem (2005) found that among men, both disability and non-disability retirement were related to low autonomy in job tasks, and they argue that hard physical work is not generally associated with early retirement among men, as the case is for women. According to Ilmarinen and Ilmarinen (2015), the physical and mental work environment, working hours, work organisation, the work community and work tasks, as well as management, are central factors influencing older employees' participation at work. Although these issues related to quality at work, the duties offered to older employees and the importance of avoiding being 'stuck in' heavy tasks are highlighted in research, systematic knowledge of how these factors are handled in the work organisation and their consequences for extended working life is lacking.

In the light of research mentioned above on work quality, occupational transitions and internal job mobility, i.e. switching tasks in the same workplace, have been designated as factors promoting working at an old age. In a study of later-life occupational transitions (Sonnega et al., 2016), it was found that most career changes were made between closely related occupations. The researchers also found that occupation workers are most likely to move into jobs that tend to be seasonal or have low barriers to entry, and that employees in physically demanding career jobs are less likely to have changed into a different occupation by age 66 .

While work mobility in younger ages is associated with career development (Rosenfeld, 1992; Bidwell and Briscoe, 2010), changes of occupation at older ages tend to involve a drop in wages (Groot and Verberne, 1997; Johnson and Kawachi, 2007; Sonnega et al., 2016). The job switching is also related to health, and studies show that downward occupational mobility in middle age has deleterious effects on women's health in later life (Wilkinson and Ferraro, 2012).

Research on internal job mobility among older people indicates that such transition above all means movement towards lower-status tasks, and it is difficult to find studies which look at promotion ladders among older people. This can be seen as an expression of the recurrent descriptions of ageing workers' bodies as 'at-risk' bodies (Katz, 2000), which is rationalised by the conflict between biological ageing processes and work requirements. Riach (2007) argues that the overall construction of a category of 'older workers' takes place by essentialising older workers' characteristics. When older workers are aligned with particular jobs, it comes down to work tasks which, rather than being based on knowledge or professional skills, are easier and less demanding. Overall, and from a critical age perspective (Krekula and Johansson, 2017), this research shows that internal job mobility 
does not constitute a unique and homogenous phenomenon, but that it has different meanings and consequences depending on age.

\section{Theoretical frames}

The analysis has a focus on the organising of age and time and how it is related to age relations at work and to older workers' participation in working life.

Organising refers here to the overarching processes in which people co-operate to create shared understanding of given situations (Weick, 1969; Czarniawska, 2014). Age is a key organising principle with great impact because it is often seen as neutral (Fineman, 2011; Krekula and Johansson, 2017). This starting-point means that age, regardless of whether it is conceptualised as resource or marginalisation, is viewed as embedded in practices, that is, as a contextual doing (Laz, 1998; Calasanti, 2003; Krekula, 2009; Krekula and Johansson, 2017; Krekula et al., 2017a, 2018).

Organising is intimately connected to constructions of social categorisations and privilege relations. Everyday organising such as designing the work environment and access to tools are examples of subtle forms of pressure as individuals act in accordance with what a system requires (Foucault, 2004). Organising age is based on age coding; distinctive practices associating a context or a phenomenon - such as internal job mobility with demarcated ages (Krekula, 2009). Coding means that some age groups are systematically favoured at the expense of others in different contexts, and that age normality is created in the form of limited age groups, and their actions assume a taken-for-granted position as an unproblematised norm (Krekula and Johansson, 2017; Krekula et al., 2017a, 2018).

Brekhus $(1996,1998)$ argues that (age) normalities are created through actors seeing one part of a dichotomy (old/young, man/woman) as epistemologically unproblematic. By labelling some categorisations with an attribute (older workers), the categorisations are marked as distinctive, while the unmarked part of the compound (workers) is simply generic. In the analysis of how job mobility is related to the construction of age normality and marginalisation, respectively, the binary marked/unmarked age is used in this article. Unmarked age here represents an unproblematised generic position, against which the marked age is constructed as a deviation (Krekula and Johansson, 2017; Krekula et al., 2017a, 2018).

Organising also takes place in terms of time (Zerubavel, 1981; Adam et al., 2008; West-Pavlov, 2012), and then often through subtle aspects. Zerubavel (1987) provides examples of time being used as semiotic codes signifying priority and respect, without the need for verbal articulation. For example, making people wait, or giving them limited access to time in public environments, signals low priority (Zerubavel, 1987; Krekula et al., 2017a). These non-verbal temporal practices are also active in the processes that create age normality (Zerubavel, 1981; Krekula et al., 2017a). Krekula and Johansson (2017; see also Krekula et al., 2017a) use the concept norma-/temporality to describe power practices based on this link between temporal organising and construction of normality, and argue that the one cannot be understood without the other.

Temporal disciplining is also exercised through social activities structured by temporal regularity such as rigid sequential structures, fixed durations, standard temporal locations and uniform rates of recurrence (Berger and Luckmann, 
1967; Zerubavel, 1981; West-Pavlov, 2012). There are several forms of temporal patterns in societal organising. While the concept 'socio-temporal order' describes temporal regulation of social entities such as families, professional groups, complex organisations and even entire nations, the 'bio-temporal order' concerns temporal regularities involving living entities, e.g. duration of pregnancy periods and age-related physical changes (Zerubavel, 1981: 2).

Temporal organisation in working life has been illustrated with the concept 'career timetable', that is, age-graded career steps which individuals are expected to follow (Lawrence, 1988). In an article on mobility in industrial companies, Martin and Strauss (1956) argue that the speed at which individuals move along specific career lines tends to follow fairly identifiable timetables, which enable individuals to predict their chances of advancement to higher levels. Lawrence (1988) argues that, while being ahead of the timetable is seen as positive, being behind is regarded as negative. A number of studies support this thesis, and show that individuals who have been promoted at the expected pace are described as being 'on time' or 'on schedule', while individuals who have been promoted faster are seen as 'ahead of time', 'ahead of schedule' or on the 'fast track'. Conversely, those who have been promoted later than expected are 'behind time', 'behind schedule', 'deadwood' or 'old timers' (Cleveland et al., 1997; Shore et al., 2003; Quintens and Matthyssens, 2010; Lawrence, 2011). This dichotomisation of on- and off-time (Zerubavel, 1981) shows that temporal regularity is based on assumptions about norms and deviation.

The analysis of the statements made on extended working life in the collected material is based on the assumption that political steering towards extended working life contributes to increasing individualisation of working-life risks and to limiting security in respect of pensions (Lewis and Giullari, 2005; Krekula et al., 2017b; Phillipsson, 2019). Standing (2011) discusses these processes in terms of the concept of the precariat, which he describes as the growing group of people in the labour market with insecure working conditions who lack basic rights and have few opportunities to make a career. According to him, the ageing population is an important factor in the growth of the precariat since older workers constitute a growing source of cheap labour, thereby also forming a group with a high risk of ending up in the precariat.

Butler (2015) and Lorey (2015) argue that precarisation means more than insecure jobs and the lack of security given by waged employment. It should rather be understood as a general experience of living with the unforeseeable. It means that everyone is affected by the processes of precarisation, and that they are the rule rather than the exception. Because insecure experiences are evident in all areas of life, a new form of disciplining is created, and precarisation becomes a particular form of exploitation that characterises contemporary society. Precarity is a basic dimension of a neoliberal governance through social insecurity. Lorey (2015) uses the concept of 'governmental precarisation' as a framework for these processes. This perspective on precarisation emphasises that it is important, although not sufficient, to display the consequences of political governance towards extended working life by identifying especially exposed groups. In addition, the range of practices also needs to be problematised through identifying the processes in, for example, work organisations that normalise and trivialise the precarisation following in the wake of policies on extended working life. 


\section{Context, material and method}

Sweden, the national context of the article, has a high proportion of older people in the population. In 2015, 19.8 per cent of the population were $65+$ (Statistics Sweden, 2016). In the same year, the average retirement age was 64.6 for women and 64.4 for men (Swedish Pensions Agency, 2016). In the age group 55-64, 71.5 per cent of the women and 76.3 per cent of the men were working in 2014 (Eurostat, 2016), which is a high number from an international perspective, clearly exceeding the 50 per cent recommended by the European Union (European Commission, 2009).

The average retirement age in Sweden for men in the occupational group discussed in this article, that is, manual workers in the metals industry, is 64.1. This is somewhat lower than the age of 65 , still regarded as the 'normal retirement age', and it is almost three years below the current highest retirement age of 67, which is seen as necessary in order to qualify for a reasonable pension (Andersson, 2015). This retirement pattern corresponds with a study on retirement-age preferences of women and men aged 55-64 years in Sweden (Soidre, 2005), which showed that qualified blue-collar workers had a significantly greater preference for early retirement than upper-rank white-collar workers.

The present study is part of a major research project on organising age in work organisations, for which data were collected through interviews, observations and text analysis in the context of two case studies (Yin, 2009). This paper is based on data from one of the cases, namely a large international steel company with a branch in Sweden. The company was chosen because it offered rich material in terms of age coding and age organising, since it had many varied units and a great number of employees of different ages. This was a male-dominated organisation.

The policy discourse on extended working life has, to a great extent, been based on a homogeneous image of a generic, individualised 'adult worker' (Lewis, 2002, 2007; Hasselhorn and Apt, 2015; Krekula and Vickerstaff, 2017). This paper has a focus on the interviews conducted with men in order to contextualise the results and contribute to complexifying the homogeneous presentations. The focus was also based on the fact that there were very few older women on the staff, which is why I do not discuss results in terms of 'older workers', but delimited to (older) men in manual work.

The material analysed consists of interviews with 11 men between the ages of 56 and 74. They worked as foundry men, fitters, welders, economists and education managers. The latter occupational groups were included to, in the first stage of the study, enable a broad and overall picture of the internal mobility that is viewed as possible and expected within the work organisation in question.

Because of the great economic fluctuations in the industry over the last decades, and several bankruptcies and new ownerships, many of the employees, including some of the men interviewed, were not employed by the company but by a staffing agency.

Respondents were partly recruited through so-called snowball sampling (Creswell, 1998). At interviews we asked for further persons aged 50+, and for special groups such as unretired persons, older persons employed via a staffing agency, and persons with duties involving a great deal of travelling or strenuous physical 
work. Some respondents were recruited in connection with observations made. The ambition was to ensure variation in terms of age, duties and experience of being employed at the company.

The interviews, made by the author and a project colleague, lasted around 60 minutes and took place in offices at the company during the respondents' workday. All interviews were digitally recorded and transcribed verbatim.

The overall topic of the interviews was age in relation to power, status and career prospects, and descriptions of the respondents' working-life transitions and retirement plans. Respondents were first asked to outline the organisation and its different units schematically. The sketches gave us an idea of the company from their perspective, and also served as a basis for talking about their units, their relocations, and their expected and unusual moves within the organisation. In short, it served as a trigger of memories and as a point of departure for our discussions (Pink, 2001).

The empirical analysis was an interpretative process carried out in several steps. A thematic analysis was made of passages in the transcribed material (Guest et al., 2012), illustrating the reasoning connected to the meanings of age, work mobility and future work. Data collection and analysis aimed to clarify the processes in question from the respondents' perspectives (Blaikie, 2007). In practice, this meant that I approached the analysis with the concepts of age and time, while social security and precarisation were introduced into the process when the central role of these concepts emerged.

\section{Temporal regimes creating age normality and disciplining}

In previous research, work mobility among older workers has mainly been related to the inability to carry out physically strenuous work (e.g. Ilmarinen and Ilmarinen, 2015; Takala and Seitsamo, 2015). Also policies have stressed the possibility of being given less strenuous tasks as a crucial factor for extended working life (SOU, 2013). While these studies have discussed the nature of work in relation to older workers, social organising of work mobility and its significance to extended working life has received less attention. In this section, I problematise the organising of work mobility by showing the presence of temporal norms creating age normality and affecting the employees' behaviour and their movements between different units in the workplace.

\section{Temporal regimes creating age normality}

In the empirical material, there are recurring descriptions of how transitions between different units and work tasks are expected to take place at a given age, and after having done something else for a certain period of time. The data also show that the opportunity to change work tasks varies with the different units in the company and that some transitions are seen as highly unlikely, as expressed in the following statements: 'The typical age to become project manager is 35 because by then you have acquired experience in construction'; 'I don't think it's common for someone to move from the foundry to other units in the company'; and 'You are probably not recruited to Start-up from administration or HR [Human Resources]'. Overall, these statements show that there is a predominant 
and shared perception of when and how employees are expected to change units and work tasks.

Perceptions of when transitions are assumed to be possible and appropriate are expressed in terms of best age for transitions, which creates a dichotomy of transitions as being on-time or off-time. In this respect, the statements harmonise with studies of career timetables (Lawrence, 1988, 2011; Cleveland et al., 1997; Shore et al., 2003; Quintens and Matthyssens, 2010). In the present material, however, not only career-making, i.e. promotion ladders, is discussed, but also horizontal moves to other units with similar status. Expressed differently, the career timetables identified do not only apply to upward career mobility but also to relocation generally in the organisation.

A suggested age for expected and appropriate transitions is gradually established through statements indicating when transitions by younger and older employees are off-time, for example, in the following statement on a career move being overdue: 'At 40-45 you start to think that it's a little too late to move from engineer to project manager.' When the younger age groups are described as being off-time, it is particularly in relation to the idea that people can be prematurely promoted to a managerial position. This is illustrated by statements such as 'Sara was her age, between 35 and 40, when she got the production job. It's pretty early in the tech unit.'

The age at which movement is assumed to be on-time is not specified directly in terms of chronological age, but emerges, as in the quotations above, through the narratives of its opposites, that is, transitions considered to be off-time, i.e. too early or too late. Categorisations of on- or off-time are thus relationally constructed. From a constructivist and critical perspective on age, in which age is seen as contextually and relationally constructed (Krekula, 2009; Krekula et al., 2017a), the processes can be understood as a concurrent construction of age normality, e.g. unmarked age, because their transitions are described as expected, unproblematic and generic. Consequently, the description of other transitions as being off-time represents a marking of corresponding age groups (Krekula and Johansson, 2017; Krekula et al., 2017a). The temporal orders on which the dichotomy of on-/off-time is based can therefore be understood as a temporal regime, and as examples of the form of power that has been referred to as norma-/temporality (Krekula and Johansson, 2017).

Some of the interviewees also mentioned how painful it can be to deviate from the temporal expectations. In the following quotation, a respondent describes what it was like to become a manager ahead of schedule:

I was 25 at the time and too young to make that kind of career move. It was tough because I got very difficult tasks from the start and it was at a time when everything was supposed to move to computers. The old timers who were supposed to support the CEO [Chief Executive Officer] were so critical of me; 'What could a young engineer have to teach us?' It was so tough that I cried a lot in the beginning.

The quote illustrates that work transitions off-time can be openly criticised, evoke strong emotions and affect individuals' wellbeing, all of which indicate that temporal orders also constitute social norms. As such, they express social values about what is seen as normal and what is seen as deviant. As indicated above, the temporal norms enforce social control through sanctions, thus producing 
shame (Heller, 1985; Scheff, 1990; Krekula, 2009). When individuals comply with the norms about when and how to move within the work organisation, it is an example of temporal adaptation to temporal norms, which has been described as a formal pattern of social organising (Zerubavel, 1981).

\section{Disciplining through fear of ageism}

The empirical material also indicates that there is a fear of ending up in a situation when it is too late to entertain the idea of moving to another unit or tasks at all. As a 74-year-old man put it: 'I'm surprised that some people haven't moved - that they stay. They have worked so long now that they couldn't even get a job as a financial manager at a company.' The fear of being off-time and finding that it is too late to change units can also affect individuals' behaviour, as in a 63-year-old man's quotation below reflecting on starting his present job:

I was at a suitable age when I began working here. However, I thought I was a little bit too old because it was the last chance to change jobs completely because otherwise I would have been $50+$ and that would have been difficult. That's what I thought then.

In this reasoning, the respondent relates to a conception of a best-before-age to start over in a new unit; in his case before the age of 50 . He states that he planned his job change so that it would take place before he became 'too old' to get the opportunity, thus illustrating a fear of age being an obstacle to career moves, which is supported by research showing that older people are discriminated against in recruitment processes (Benedick et al., 1999; Kalavar, 2001; Nelson, 2005; Gee et al., 2007; Neumark, 2009). Fear of age discrimination made this respondent take action before he got too old. In the words of Foucault (1991), this can be an expression of disciplining, where temporal norms and worries about ageism are internalised and lead to the attempt to harmonise behaviour and the norm.

Overall, the results above display the central role of socio-temporal orders in work organisations. They illustrate that the internal work mobility is regulated by normative assumptions on temporality, e.g. that they are based on temporal regimes. They also show that conceptions of career moves as being on- or off-time are constructed parallel with age-normality constructions, and that the temporal order constitutes a disciplining element for the employees; it makes individuals plan for avoiding future job limitations as a result of ageism. This disciplining can thus be seen as an example of the 'governmental precarisation' that Lorey (2015) describes as governing through social insecurity.

\section{Changing corporate strategies with prevailing social insecurity}

In parallel with the temporal orders described above, where transitions within the organisation at certain delimited ages are seen as expected, other movements appear to be outside the socio-temporal order. This section deals with workplace mobility involving a change from physically strenuous tasks to less physically demanding tasks, which I discuss in relation to established temporal orders and vulnerability to insecurity. 


\section{Individualisation of the risks of working life}

The analysed data provide several examples of respondents describing many of their work tasks as heavy and difficult to combine with a long working life. It is, for example, stated that 'I don't know if we should be doing this when we're over 60, it's too heavy'; 'In heavy industry, you can feel it's hurting'; and 'If you think that an industrial worker should work until he is 67, you don't know the reality of this job.' These quotes indicate that there is an apparent need for less physically strenuous tasks if working at an older age should be possible. This relates to studies showing that both preferred retirement and the actual average retirement age are lower among occupational groups in physically demanding work (Soidre, 2005; Andersson, 2015), and to research pointing to the difficulties of maintaining work ability in jobs with physically demanding tasks (Pohrt and Hasselhorn, 2015; Takala and Seitsamo, 2015).

When the respondents talked about internal mobility, these transitions towards physically easier tasks were not mentioned. However, the theme was commented on when we explicitly asked them about the opportunities for older workers to get other work tasks, and then the answers varied greatly. Someone said that he had made that type of transition, others questioned whether the company had so-called 'retreat positions', while some thought that the option existed since they had heard about employees who had been given easier tasks when unable to perform their normal duties. A 56-year-old foundry repair man, for example, said: 'If you cannot manage because the work is too heavy, I think "the Company" will take care of it. I have noticed that some people have gotten easier tasks as they get older.'

The many different types of answers and levels of uncertainty about which transitions can actually be made indicate that they are in the form of individualised arrangements and not based on formal routines, if at all possible. There are no established practices expressing that the company values the competences of older employees. The demand for tasks adapted to the individual is left to the individual to handle. The comments indicate that these types of transitions are not socially expected or recognised. Using Zerubavel's (1981) terminology, they can be described as a bio-temporal order construction with a focus on physical bodies, rather than as incorporated in the socio-temporal order with its relation to social structures and processes in the organisation. Social processes are, in other words, redefined as a matter of individual physical bodies.

The analysed material further shows that the exclusion of alternative tasks from the socio-temporal order has emerged over time, as expressed in the following:

If you're working here, there aren't that many alternatives but we follow the rules of 'the Company', We cannot offer someone an easier position before retirement the way we used to do. All those types of jobs have been removed. When I was younger there were lots of such jobs. If my body says, 'No', there's not much I can do, unfortunately. If that's the case, in the end you'll have to stop working because we don't have those types of jobs anymore. We're a joint-stock company and if one thing crashes everything crashes. We went bankrupt in the past and 100 people lost their jobs, 30 got to stay. There's no room in the budget for easier jobs, so you have to bring it up with the HR department ... It's hard to find retreat positions today. It used to be easier and people could do more simple things like sweeping the floors or cleaning. (Man, 59 years old, foreman at the foundry) 
The quotation suggests that it has been possible to get physically easier work tasks but that this no longer applies for economic reasons. The absence of formal routines supporting older employees corresponds with previous reports showing that the majority of employers in most countries lack measures to retain and recruit older workers (Walker, 2005; Van Dalen et al., 2009; Jensen and Møberg, 2012). The argument that this is due to economic reasons projects the company as an anorectic organisation where staffing is continuously reduced in relation to the demand of the products in question. On the basis of descriptions of downsizing as a globally established practice since the 1980s (Radnor and Boaden, 2004; Tyler and Wilkinson, 2007), this can be seen more as a manifestation of contemporary corporate strategies than as a characteristic feature of this company.

In the quotation above, it is further stated that tasks previously allocated to older employees were simple tasks like cleaning and sweeping the floors, which is tantamount to downward mobility and not a way to take advantage of the professional skills developed during a life of work experience. This is a trend also noted in previous studies (Riach, 2007; Wilkinson and Ferraro, 2012). The reason that the company previously offered other tasks to older workers was not then that there was a different and more positive view of their competences than today, or that active efforts were made to make use of their knowledge and experiences.

Taken together, the results indicate an individualisation of risks for older workers in this company, where the employer's previous responsibility for supporting older workers' continued participation in the workplace through reallocation of tasks, based on a socio-temporal order over time, has been turned into a problem for the individual, and justified on economic grounds.

\section{Manifestations of precarisation}

The results also show that for some groups of employees there is an added element of insecurity in terms of employment and work tasks.

In the narratives of the respondents employed by staffing agencies there is a recurring theme of lack of support in the organisation and of being in a situation of having to have the strength to perform tasks, as in the following statements: 'There are no retreat positions for those of us who come from staffing agencies' and

Those who work on the assembly line, they are being looked after, of course. But those of us with temporary positions, we don't have a line of retreat. Yes, I know that there are different types of jobs for employees and people from staffing agencies.

A further example of the perceived absence of support for this group is the following:

I actually don't know what the situation is like today with retreat positions. Back in time, you would always get easier work tasks when you got older. But I don't think it's like that anymore. Nowadays, I think they will take you to an old people's home if you can't manage. It's a little bit more like that now. At least if you're hired through a staffing agency. (Man, 63 years old, fitter and welder) 
The quote indicates that those who are hired via staffing agencies only have a place in the organisation as long as they can perform what they have been hired to do. The phrase 'if you can't manage' suggests that the responsibility for future work rests with the individual, as discussed above.

Some of the staff in this company were in charge of installing the machines that the company manufactures on site in other countries, which meant that they were expected to have around 150 travelling days per year, which was considered difficult to combine with family life and entails vulnerability if they should be taken ill abroad. Stories were told about employees changing jobs when they or a family member were ill. This work also meant insecurity about future work, not least among workers employed for limited periods and jobs. A travelling consultant, employed via a staffing agency, described the situation in this way: 'If I can't travel anymore, I will have to find another job. After all, my job is to travel.'

For the staffing agency, and other temporary employees, insecurity related to whether or not there would be a continued need of their services or not. A 63 -year-old man gave an example of this when reflecting on for how long he was planning to work: 'I plan to continue working until they don't want me anymore.'

The empirical material displays that the respondents share the general insecurity concerning working at an older age with physically demanding jobs in this company without formal procedures supporting elderly people who have problems handling their tasks and where the need to get other tasks is presented as an individual problem. Results also indicate that precarisation is expanding in different degrees among various employee groups. For staffing agency employees, insecurity also included narrowly defined tasks and periods of employment, and the knowledge that there may be no work beyond the fixed-term employment.

\section{Concluding remarks}

This article has looked at work mobility among men in physically demanding workplaces, and its temporal organising. By problematising the work mobilities that are regarded as possible, expected and coveted, I have pointed to the presence of temporal regimes and the key role which they play in the work organisation and for the employees' opportunities to continue working at an older age. Together, the results show the need for more thorough studies of how work ability relates to the physical aspects of the workplace as well as to its social organising, including temporal practices. They also show the fruitfulness of bringing time and temporality into socio-gerontological studies and into sociology of age (Krekula and Johansson, 2017).

Drawing on the idea of temporal organisation as a power practice, I have illustrated that internal work mobility is surrounded by normative assumptions, which, if violated, also affect individuals' wellbeing. Consequently, I have referred to the assumptions as temporal regimes and shown that they create an age normality against which the older workers are marked as problematic in terms of mobility in the organisation. The article thus contributes to research on age relations, and sheds light on the fruitfulness of identifying age groups that constitute age normality and the practices and discourses that produce age normality through concurrent marking of other age groups (Krekula et al., 2017a). The study also supports previous arguments that age-based privileges are constructed through notions of time 
(Krekula and Johansson, 2017; Krekula et al., 2017a) and contributes to such research by illustrating the disciplining that is formed through expectation of timing transitions with temporal norms in the workplace. By demonstrating how the temporal processes relate to disciplining the employees, the article also contributes to placing the debate on extended working life in a contemporary social analysis. The results illustrate that the local socio-temporal order make up a disciplining element of the employees as they, from an early stage of their working life, are pressured to plan and act to create a safer future for themselves. In this material, two aspects of disciplining appear: in relation to feared ageism and to expected physical limitations. The results display the place ageism has in the work organisations. The processes discussed here, in which fear of ageism creates disciplining, emphasise the central position which ageism can have in neoliberal governance by creating social insecurity among older workers ( $c f$. Butler, 2015; Lorey, 2015).

The study also shows that over time insecurity has been individualised and that this change is not based on a changed perception of elderly people, but rather on developed economic corporate strategies. When alternative tasks are offered to older workers, it represents a downward mobility, as shown by previous studies (Riach, 2007; Wilkinson and Ferraro, 2012). Organising in the studied work organisation, in other words, is narrowly based on the notion that older workers' bodies, knowledge and skills are problematic, that is, a marking of old age. This supports Standing's (2011) claim that older workers run a greater risk of precarisation, emphasising that this ultimately depends on the organising of work on the basis of younger ages as the norm. These results indicate that we need more knowledge of the organising of workplaces and age normality related to older workers' wellbeing and retirement strategies.

Above, we have also seen that individualisation of risk in old age is highly related to the use of staffing agencies, and the dismantling of corporate responsibility. Against the backdrop of increasing insecure employment in terms of pension and guaranteed hours (OECD, 2015), the results are noteworthy. They indicate a need to highlight company strategies and what they mean from an age perspective; not least to older workers. Extensive research has shown that the political ambition to implement extended working life has different consequences for groups of elderly people, and that, for instance, gender (Loretto and Vickerstaff, 2013), sociodemographic variables and sectoral composition of the economy (Phillipson and Smith, 2005) and care of next-of-kin (Lewis, 2007; Dewilde, 2012) are central factors. In addition, this study shows that the varying employment terms and vulnerability of older workers are also created through local practices and routines in work organisations. Like other studies (Hasselhorn and Apt, 2015; Krekula and Vickerstaff, 2017; Phillipson, 2019), this study shows the need to introduce organisational practices and corporate strategies in the debate on extended working life.

At the overall level, the study points to the importance of workplace organising to the political initiatives for extended working life. Against the background of the mechanisms of workplace organising, the policies describing older workers' retirement trends as self-serving and problematic (for a discussion, see Krekula and Vickerstaff, 2017) appear as simplified and uninformed about workplace terms for older workers. The rhetoric contributes to concealing the central role that organisational processes play in creating insecurity among older workers, and in normalising social insecurity related to extended working life. 
Acknowledgements. This paper is based on work from COST Action IS1409 'Gender and health impacts of policies extending working life in western countries', supported by COST (European Cooperation in Science and Technology).

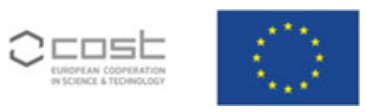

Financial support. This work was supported by the Swedish Research Council for Health, Working Life and Welfare (2012-1112).

\section{References}

Adam B, Whipp R and Sabelis I (2008) Choreographing time and management: traditions, developments, and opportunities. In Whipp R, Adams B and Sabelis I (eds), Making Time. Time and Management in Modern Organizations. New York, NY: Oxford University Press, pp. 1-30.

Andersson R (2015) Vem kan Jobba till 67? En Rapport om Medelpensioneringsåldern i olika LO yrken [Who Can Work Until 67? A Report on the Average Retirement Age in Different LO Professions]. Stockholm: The Swedish Trade Union Confederation (LO). Available at http://www.lo.se/home/lo/res. nsf/vRes/lo_fakta_1366027478784_vem_kan_jobba_till_67_pdf/\$File/Vem_kan_jobba_till_67.pdf.

Benedick M, Brown LE and Wall K (1999) No foot in the door: an experimental study of employment discrimination against older workers. Journal of Aging \& Social Policy 10, 4, 5-23.

Bennington L (2001) Age discrimination: converging evidence from four Australian studies. Employee Responsibilities and Rights Journal 13, 125-134.

Berger PL and Luckmann T (1967) The Social Construction of Reality. Harmondsworth, UK: Penguin.

Bidwell M and Briscoe F (2010) The dynamics of interorganizational careers. Organization Science 21, 1034-1053.

Blaikie N (2007) Approaches to Social Enquiry. Advancing Knowledge. Cambridge: Polity.

Blekesaune M and Solem PE (2005) Working conditions and early retirement. A prospective study of retirement behavior. Research on Aging 27, 3-30.

Brekhus W (1996) Social marking and the mental coloring of identity: sexual identity construction and maintenance in the United States. Sociological Forum 11, 497-522.

Brekhus W (1998) A sociology of the unmarked: redirecting our focus. Sociological Theory 16, 34-51.

Butler J (2015) Foreword. In Lorey I, State of Insecurity. Government of the Precarious. London: Verso Futures, pp. vii-xi.

Butler RN (1969) Age-ism: another form of bigotry. The Gerontologist 9, 243-246.

Cadiz DM (2010) The Effects of Ageism Climates and Core Self-evaluations on Nurses' Turnover Intentions, Organizational Commitment, and Work Engagement. Ann Arbor, MI: Portland State University.

Cahill K, Giandrea M and Quinn J (2015) Retirement patterns and the macroeconomy, 1992-2010: the prevalence and determinants of bridge jobs, phased retirement, and reentry among three recent cohorts of older Americans. The Gerontologist 55, 384-403.

Calasanti T (2003) Theorizing age relations. In Biggs S, Lowenstein A and Hendricks J (eds), The Need for Theory: Critical Approaches to Social Gerontology. Amityville, NY: Baywood, pp. 199-218.

Chan S and Stevens AH (2001) Job loss and employment patterns of older workers. Journal of Labor Economics 19, 484-521.

Cleveland J, Shore I and Murphy K (1997) Person and context oriented perceptual age measures. Journal of Organizational Behavior 18, 239-251.

Creswell JW (1998) Qualitative Inquiry and Research Design. London: Sage.

Czarniawska B (2014) A Theory of Organizing. Cheltenham, UK: Edward Elgar Publishing.

Dewilde C (2012) Lifecourse determinants and incomes in retirement: Belgium and the United Kingdom compared. Ageing \& Society 32, 587-615.

Dvorkin M and Shell H (2015) A Cross-country Comparison of Labor Force Participation. Federal Reserve Bank of St. Louis Economic Synopses 17. Available at https://research.stlouisfed.org/publications/economic-synopses/2015/07/31/a-cross-country-comparison-of-labor-force-participation/.

European Commission (2009) Dealing with the Impact of an Ageing Population in the EU. Brussels: European Commission. Available at http://www.cedefop.europa.eu/en/news-and-press/news/dealingimpact-ageing-population-eu-2009-ageing-report. 
Eurostat (2016) Employment Statistics. Available online at http://ec.europa.eu/eurostat/statistics-explained/ index.php/Employment_statistics.

Fevre R (2011) Still on the scrapheap? The meaning and characteristics of unemployment in prosperous welfare states. Work, Employment and Society 25, 1-9.

Fineman S (2011) Organizing Age. Oxford: Oxford University Press.

Foucault M (1991) Discipline and Punish: The Birth of the Prison. London: Penguin Books.

Foucault M (2004) Society Must Be Defended: Lectures at the College de France, 1975-76. New York, NY: Picador.

Gee G, Pavalko EK and Long JS (2007) Age, cohort and perceived age discrimination: using the life course to assess self-reported age discrimination. Social Forces 86, 265-290.

Groot W and Verberne M (1997) Aging, job mobility, and compensation. Oxford Economic Papers 49 , 380-403.

Guest G, MacQueen KM and Namey EE (2012) Applied Thematic Analysis. London: Sage.

Hasselhorn HM and Apt W (2015) Understanding Employment Participation of Older Workers: Creating a Knowledge Base for Future Labour Market Challenges. Research Report. Berlin: Federal Ministry of Labour and Social Affairs (BMAS) and Federal Institute for Occupational Safety and Health (BAuA). Available at http://www.jp-demographic.eu/wp-content/uploads/2015/07/JPIUEP_Brochure.pdf.

Heller A (1985) The Power of Shame: A Rational Perspective. London: Routledge \& Kegan.

Henkens K, Sprengers $\mathbf{M}$ and Tazelaar F (1996) Unemployment and the older worker in The Netherlands: re-entry into the labour force or resignation. Ageing \& Society 16, 561-578.

Hirsch BT, MacPherson DA and Hardy MA (2000) Occupational age structure and access for older workers. Industrial and Labor Relations Review 53, 401-418.

Ilmarinen J (1997) Aging and work - coping with strengths and weaknesses. Scandinavian Journal of Work, Environment and Health 23, 3-5.

Ilmarinen J (2006) The ageing workforce - challenges for occupational health. Occupational Medicine 56, $362-364$.

Ilmarinen J and Ilmarinen V (2015) Work ability and aging. In Finkelstein LM, Truxillo DM, Fraccaroli F and Kanfer R (eds), Facing the Challenges of a Multi-age Workforce: A Use-inspired Approach. New York, NY: Routledge, pp. 134-156.

James JB, Matz-Costa C and Smyer MA (2016) Retirement security: it's not just about the money. American Psychologist 71, 334-344.

Jensen PH and Møberg RJ (2012) Age management in Danish companies: what, how and how much? Nordic Journal of Working Life Studies 2, 3, 49-65.

Johnson RW and Kawachi J (2007) Job changes at older ages: effects on wages, benefits, and other job attributes. The Urban Institute, The Retirement Project Discussion Paper 07-03. Available at http:// webarchive.urban.org/UploadedPDF/311435_Job_Changes.pdf.

Kail BL and Warner DF (2013) Leaving retirement: age-graded relative risks of transitioning back to work or dying. Population Research and Policy Review 32, 159-182.

Kalavar JM (2001) Examining ageism: do male and female college students differ? Educational Gerontology 27, 779-811.

Katz S (2000) Busy bodies. Activity, aging and the management of everyday life. Journal of Aging Studies 14, 135-152.

Krekula C (2009) Age coding: on age-based practices of distinction. International Journal of Ageing and Later Life 4, 2, 7-31.

Krekula C, Arvidson M, Heikkinen S, Henriksson A and Olsson E (2017) On grey dancing: constructions of age-normality through choreography and temporal codes. Journal of Aging Studies 42C, 38-45.

Krekula C, Engström L-E and Alvinius A (2017) Sweden: an extended working life policy which neglects gender and health considerations. In Ní Léime A, Street D, Vickerstaff S, Krekula C and Loretto W (eds), Gender and Extended Working Life: Cross-national Perspectives. London: Policy Press, pp. 157-174.

Krekula C and Johansson B (2017) Introduktion [Introduction]. In Krekula C and Johansson B (eds), Kritiska Åldersstudier [Critical Age Studies]. Malmö, Sweden: Studentlitteratur.

Krekula C, Nikander P and Wilinska M (2018) Multiple marginalisations based on age. Gendered ageism and beyond. In Ayalon L and Tesch-Roemer C (eds), Contemporary Perspectives on Ageism. NY: Springer Publisher, pp. 33-50. 
Krekula C and Vickerstaff S (2017) Theoretical and conceptual issues in the extending working lives agenda. In Ní Léime A, Street D, Vickerstaff S, Krekula C and Loretto W (eds), Gender, Ageing and Extended Working Life: Cross-national Perspectives. London: Policy Press, pp. 27-52.

Larsen M (2008) Does quality of work life affect men and women's retirement planning differently? Applied Research in Quality of Life 3, 23-42.

Lawrence BS (1988) New wrinkles in the theory of age: demography, norms, and performance rating. Academy of Management Journal 31, 309-337.

Lawrence B (2011) The Hughes Award Lecture: who is they? Inquiries into how individuals construe social context. Human Relations 64, 749-773.

Laz C (1998) Act your age. Sociological Forum 13, 85-113.

Lewis J (2002) Gender and welfare state change. European Societies 4, 331-357.

Lewis J (2007) Gender, ageing and the 'new social settlement': the importance of developing a holistic approach to care policies. Current Sociology 55, 271-286.

Lewis J and Giullari S (2005) The adult worker model family, gender equality and care: the search for new policy principles and the possibilities and problems of a capabilities approach. Economy and Society 34, 76-104.

Loretto W, Duncan C and White PJ (2000) Ageism and employment: controversies, ambiguities and younger people's perceptions. Ageing \& Society 20, 279-302.

Loretto W and Vickerstaff S (2013) The domestic and gendered context for retirement. Human Relations 66, 65-86.

Lorey I (2015) State of Insecurity. Government of the Precarious. London: Verso Futures.

Lund T and Villadsen E (2005) Who retires early and why? Determinants of early retirement pension among Danish employees 57-62 years. European Journal of Ageing 2, 275-280.

Maestas N (2010) Back to work: expectations and realizations of work after retirement. Journal of Human Resources 45, 718-748.

Martin NH and Strauss AL (1956) Patterns of mobility within industrial organizations. The Journal of Business 29, 101-110.

Nelson TD (2005) Ageism: prejudice against our feared future self. Journal of Social Issues 61, 207-221.

Neumark D (2009) The age discrimination in employment act and the challenge of population aging. Research on Aging 31, 41-68.

Nilsson K (2016) Conceptualisation of ageing in relation to factors of importance for extending working life - a review. Scandinavian Journal of Public Health 44, 490-505.

Organisation for Economic Co-operation and Development (OECD) (2015) Employment Outlook 2015. Paris: OECD Publishing.

Phillipson C (2019) 'Fuller' or 'extended' working lives? Critical perspectives on changing transitions from work to retirement. Ageing \& Society 39, 629-650.

Phillipson C and Smith A (2005) Extending Working Life: A Review of the Research Literature (Research Report No. 299). London: Department for Work and Pensions. Available online at http://dwp.gov.uk/ asd/asd5/rports2005-2006/rrep299.pdf.

Pink S (2001) Doing Visual Ethnography: Images, Media and Representation in Research. London: Sage.

Pohrt A and Hasselhorn HM (2015) Work factors. In Hasselhorn HM and Apt W (eds), Understanding Employment Participation of Older Workers: Creating a Knowledge Base for Future Labour Market Challenges. Research Report. Berlin: Federal Ministry of Labour and Social Affairs (BMAS) and Federal Institute for Occupational Safety and Health (BAuA), pp. 48-49.

Quintens L and Matthyssens $\mathbf{P}$ (2010) Involving the process dimensions of time in case-based research. Industrial Marketing Management 39, 91-99.

Radnor ZJ and Boaden R (2004) Developing an understanding of corporate anorexia. International Journal of Operations \& Production Management 24, 424-440.

Riach K (2007) 'Othering' older worker identity in recruitment. Human Relations 60, 1701-1726.

Riach K (2009) Managing 'difference': understanding age diversity in practice. Human Resource Management Journal 19, 319-335.

Rosenfeld RA (1992) Job mobility and career processes. Annual Review of Sociology 18, 36-61.

Scheff TJ (1990) Microsociology: Discourse, Emotion, and Social Structure. Chicago, IL: The University of Chicago Press.

Schwartz DA and Kleiner BH (1999) The relationship between age and employment opportunities. Equal Opportunities International 18, 5/6, 105-110. 
Shore LM, Cleveland JN and Goldberg CB (2003) Work attitudes and decisions as a function of manager age and employee age. Journal of Applied Psychology 88, 529-537.

Smeaton D and White $\mathbf{M}$ (2016) The growing discontents of older British employees: extended working life at risk from quality of working life. Social Policy and Society 15, 369-385.

Soidre T (2005) Retirement-age preferences of women and men aged 55-64 years in Sweden. Ageing \& Society 25, 943-963.

Sonnega A, Helppie McFall B and Willis RJ (2016) Occupational transitions at older ages: what moves are people making? Michigan Retirement Research Center, Working Paper WP 2016-352. Available at http:// www.mrrc.isr.umich.edu/publications/papers/pdf/wp352.pdf.

SOU (2013) Åtgärder för ett Längre Arbetsliv. Slutbetänkande av Pensionsåldersutredningen [Measures for an Extended Working Life. Final Report by the Government Commission for Longer Working Life and Retirement Age]. 2013:25. Stockholm: SOU.

Standing G (2011) The Precariat. The New Dangerous Class. London: Bloomsbury Academic.

Statistics Sweden (2016) Äldre i Befolkningen [Older People in the Population]. Available at http://www.scb. se/sv_/Hitta-statistik/Statistik-efter-amne/Befolkning/Befolkningens-sammanssattning.

Swedish Pensions Agency (2016) Medelpensioneringsålder och Utträdesålder [Expected Effective Retirement Age and Retirement Age]. 2016:3. Stockholm: The Swedish Pensions Agency.

Takala E-P and Seitsamo J (2015) Work ability. In Hasselhorn HM and Apt W (eds), Understanding Employment Participation of Older Workers: Creating a Knowledge Base for Future Labour Market Challenges. Berlin: Federal Ministry of Labour and Social Affairs (BMAS) and Federal Institute for Occupational Safety and Health (BAuA), pp. 52-55.

Thorsen S, Rugulies R, Løngaard K, Borg V, Thielen K and Bjorner JB (2012) The association between psychosocial work environment, attitudes towards older workers (ageism) and planned retirement. International Archives of Occupational and Environmental Health 85, 437-445.

Tyler M and Wilkinson A (2007) The tyranny of corporate slenderness: 'corporate anorexia' as a metaphor for our age. Work, Employment and Society 21, 537-549.

Van Dalen HP and Henkens K (2002) Early-retirement reform: can it and will it work? Ageing \& Society 22, 209-231.

Van Dalen HP, Henkens K and Schippers J (2009) Dealing with older workers in Europe: a comparative survey of employers' attitudes and actions. Journal of European Social Policy 19, 47-60.

Vickerstaff S and Loretto W (2017) The United Kingdom - a new moral imperative: live longer, work longer. In Ní Léime A, Street D, Vickerstaff S, Krekula C and Loretto W (eds), Gender, Ageing and Extended Working Life: Cross-national Perspectives. London: Policy Press, pp. 175-192.

Walker A (2005) The emergence of age management in Europe. International Journal of Organisational Behaviour 10, 685-697.

Weick KE (1969) The Social Psychology of Organizing. New York, NY: McGraw-Hill.

West-Pavlov R (2012) Temporalities. New York, NY: Routledge.

Wilkinson JA and Ferraro KF (2002) Thirty years of ageism research. In Nelson TD (ed.), Ageism: Stereotyping and Prejudice Against Older Persons. Cambridge, MA: MIT Press, pp. 339-358.

Wilkinson LR and Ferraro KF (2012) Does occupational mobility influence health among working women? Comparing objective and subjective measures of work trajectories. Journal of Health and Social Behavior 53, 432-447.

World Health Organization (2015) World Report on Ageing and Health. Luxembourg: World Health Organization. Available at http://apps.who.int/iris/bitstream/10665/186463/1/9789240694811_eng.pdf.

Yearta SK and Warr P (1995) Does age matter? Journal of Management Development 14, 7, 28-35.

Yin RK (2009) Case Study Research: Design and Methods. London: Sage.

Zerubavel E (1981) Hidden Rhythms: Schedules and Calendars in Social Life. Berkeley, CA: University of California Press.

Zerubavel E (1987) The language of time: toward a semiotics of temporality. The Sociological Quarterly 28, 343-356.

Cite this article: Krekula C (2019). Time, precarisation and age normality: on internal job mobility among men in manual work. Ageing \& Society 39, 2290-2307. https://doi.org/10.1017/S0144686X1800137X 